\title{
The Enlightenment of the "whole language approach" theory to the reform of College English Teaching
}

\author{
Wang qian ${ }^{1 a}$ \\ ${ }^{1}$ Yingcai University ,Shandong,250104,China \\ awangqian666777@163.com
}

\begin{abstract}
Keywords:whole language approach; English teaching; reform
Abstract.With the rapid growth of China's national economy and the improvement of science and technology, China's education is also flourishing, while English education has been the national and social public attention. In the course of English Teaching in many colleges and universities in China, there are various problems. If these problems cannot be solved in time, it will seriously affect the quality of English Teaching in schools. At the moment, the importance of English is constantly improving, and many universities and related teaching staff in China have already paid great attention to English teaching. Now, many of our colleges and universities in English teaching, has also been applied to the whole language approach in English teaching, the author actively explore the existence of whole language approach in English teaching, so as to analyze the whole language theory on College English teaching reform.
\end{abstract}

\section{Introduction}

With the continuous progress of the times, colleges and universities have already innovated English teaching mode when they are teaching english. In recent years, under the background of the new curriculum standard, there are some problems and challenges in the process of promoting English Teaching in various colleges and universities in china. The whole language act is actually a kind of language education theory, and the whole research and development are applied to the English Teaching of every big university, and it has a positive influence. Language teaching is the most important component of English teaching reform in universities and colleges, and it has a positive impact on teaching reform of major universities.[1]

\section{Overview of the whole language act}

The whole element theory was first originated in the United States, from the United States on the field of education, the whole language approach is teaching English as a whole, through listening speaking reading and writing and other forms, to conduct a comprehensive and in-depth English Teaching for students, whole language teaching methods, from improve the students' interest in learning English, so as to improve the performance of students, to cultivate students' ability to learn english. The whole language theory, generally through theoretical concepts to establish the concept and system of the whole, and then the whole teaching of English, in this process will be the integration of teaching resources, creates a good English learning atmosphere for students. The teaching method of the whole language approach focuses on respecting the students' subjective states, starting from the basic needs of the students, and actively cultivating the students"s ability to learn english. The teaching process of English language curriculum integration method is applied to the universities, teachers should fully respect the dominant position of students, not blindly play the leading role of teachers in the teaching process, teachers should actively guide students' autonomous learning, pay attention to the students' listening, speaking, reading and writing ability training, not only to to teach the students to learn scientific knowledge fully, but also fundamentally to cultivate students' language ability and writing ability, at the same time, teachers should actively innovate whole language teaching methods, make some scientific and reasonable teaching plan, teaching English will be better applied to the whole language approach in college.[2]

\section{The problems of the whole language approach in the course of English Teaching}

3.1. English teaching, the overall quality of teachers needs to be improved

The whole language approach applied to English Teaching in University, if you want to play the whole language teaching method, first of all, the most important problem is that teachers need to 
establish the correct teaching idea, when in a scientific and reasonable use of English teaching materials, actively guide the students to learn the extracurricular English teaching knowledge of English textbooks in English knowledge is limited, can not meet the students' knowledge of English learning needs fundamentally, knowledge content of students' active learning English teaching, students learning English can broaden the scope of fundamentally good development so as to promote students' English learning ability. When universities actively promote English teaching work, it should be positive for students to create a relaxed and pleasant learning atmosphere, and actively guide the students to learn, and also actively guide the students moral education teachers communicate, improve students' English language communication skills in order to fundamentally ease. In the process of major college English Teaching in the actual work, the overall quality of the College English Teaching of teachers is not high enough, scientific and reasonable to guide the students to learn English, if you want to promote university students' English learning achievement can be improved, the overall quality of training teachers of colleges and Universities should focus on the the English, in order to create a good learning atmosphere and learning conditions of students' learning.[3]

3.2Class settings in Colleges and universities are not reasonable enough

When universities actively promote English teaching work, if you want to maximize the whole language teaching advantages, should be scientific and reasonable set of related classes, but in the practical English Teaching in universities, a class of settings and not reasonable, many colleges and universities most of them are in large class teaching mode, the small number of classes are dozens, even hundreds, if want to let the teaching of English teachers, in the face of a class of hundreds of students to carry on the teaching, it will fundamentally increase the burden for teachers' teaching and teaching difficulty, but also hinder the whole language teaching method serious advantage can be a good play. The number of classes in English teaching is too large, which is very unfavorable for teachers to teach students the whole language approach.[4]

\subsection{In the English teaching process, the teaching rating is not reasonable enough}

With the continuous development of China's education, China has developed a standardized student rating assessment standards, such as the entrance exam and college entrance examination, mostly in the examination results of students to grade and assessment. In many of our existing rating assessment exam, mostly over emphasis on the students' scores, thus ignoring the concept of learning culture and improve learning ability, in the process of English Teaching in English teaching and has not established the evaluation system of perfect, but still there are a lot of College English teaching evaluation system for the existing assessment standard of the students, in the process of a lot of students' writing ability relatively excessive attention, it also ignores the cultivation of students' reading ability and expression, which to some extent hinders the application of whole language teaching is serious in English in the process of teaching, which is not conducive to play the whole language teaching method in the teaching advantage fundamentally, but also not conducive to fundamentally improve the students' English learning Power.[5]

3.4The cognition of the whole linguistic approach is not enough

Since the last century since 90s, in China it has been the rise of whole language teaching theory, for each university teaching work, actively use department and the development of teaching theory can provide some convenience for colleges and universities English teaching, promote English Teaching in Colleges and universities in my work China carried out smoothly, but also can guarantee the quality of teaching. But the actual English Teaching in Colleges and universities don't have enough cognition of the whole language teaching theory, some teachers still use traditional teaching methods to English teaching, in the process of using the method of whole language teaching, too much attention to the use of language, ignoring the teaching standard on English vocabulary and grammar, so long will lead to students' English pronunciation is not standard. When in College English teaching, the whole language teaching method is the existence of certain challenges at the same time, many universities are not the overall $\mathrm{R} \& \mathrm{~d}$ be realistic, not with the students' English learning itself fundamentally, to make scientific and reasonable teaching plan, whole language 
approach in English language teaching will be better applied to the students, which to some extent is seriously hindered the students' English learning achievement promotion.[6]

\section{The reform measures of College English Teaching}

In general, when actively promote the English teaching method in College English language as a whole, the whole of whole language teaching theory more prominent language, pays more attention to the cultivation of students' language ability. When teaching English in Colleges and universities, we should pay attention to the creation of students' English learning atmosphere, and fundamentally create a good and comfortable English learning environment for students. But the actual process of English Teaching in Colleges and universities in the whole language approach is more focus on English learning content, to cultivate comprehensive ability to learn English at the same time, this also to the music teaching of colleges and universities of our country reform brought certain implication and influence.

4.1The implementation of standardized management of English Teaching

A considerable amount of teaching time and repeated knowledge teaching are two practical problems in the course of English Teaching in our country. Both the primary school English teaching, English Teaching in high school or college English teaching, in the process of English teaching, the implementation of standardized teaching management, can solve the existing process of English Teaching in our country, and at the same time to improve our existing English teaching system. The process of English Teaching in many colleges and universities in China are now actively adopt normative management system, normative English teaching management system can optimize the English teaching resources fundamentally, and to each stage of the students on the English learning knowledge linking appropriate, so as to avoid the students each stage of the process of learning English, learning English phenomenon of repetitive knowledge points. Major universities should actively innovate in English teaching mode, actively formulate a scientific and rational English teaching program, and prepare an English syllabus to regulate and guide students' English learning. If you want to be in the process of English teaching, to maximize the advantages of English teaching syllabus, first of all, the most important thing is to make a scientific and reasonable setting of English teaching syllabus, in the English teaching syllabus in English teaching should reflect the scientific, at the same time also should actively reflect the continuity. Integrity should fully reflect the language, in this process, students should not only focus on the English writing skills, but also should pay attention to cultivate and improve fundamentally on the expression of the students' English ability, so as to promote the students all aspects of English learning.[7]

4.2Actively implement the whole language act and reform the English teaching mode

When actively promote English teaching work in Colleges and universities, time consuming and low efficiency of English teaching is more widespread, contributed to the cause of the problem is there are many aspects, one of the most important factors that lead to the concept of English teaching is more traditional English teaching mode is not advanced. For English majors, in the course of learning, they should not only fully grasp adequate theoretical knowledge of English, but also should train students to master certain English practical ability. English and other subjects are not the same, when learning English in students, not only to learn enough English knowledge, it should also be flexible use of English scientific and reasonable, in order to fundamentally promote the school English teaching work smoothly, and improve the students' English learning ability, promote the development of physical and mental the health of the students.

4.3Reform the test and evaluation system in Colleges and universities, and actively realize quality education

For the development of universities, it is extremely important to establish a scientific and reasonable test and evaluation system. Scientific and rational evaluation system can promote the smooth progress of school teaching to a certain extent. For the College English teaching, while actively promoting the work of English teaching, English test should be scientific and reasonable evaluation system to implement the whole English teaching work, the maximum is the teaching system plays a supporting role in the English teaching, so that the system can be counterproductive in English teaching. English test and assessment system should be in accordance with the term set, 
combined with the English learning situation of the university students, students comprehensive and deep English testing and evaluation, so as to promote the English Teaching in Colleges and universities work smoothly.

4.4Change the existing English teaching model and from a management system from primary school to University

nowadays, when promoting English Teaching in many universities in China, most of them will be influenced by the traditional teaching concepts, while ignoring the dominant position of students in learning English, the students in the classroom cannot have good self play. Therefore, in English Teaching in colleges, universities and related English teaching staff should actively change the mode of English teaching, the ideal should be scientific and reasonable setting of English teaching class, set up teaching in small classes to maximize the full understanding of students' English learning, English learning methods to choose the most suitable for students and improve the students' enthusiasm of learning English fundamentally, in order to maximize the role of students in the English learning process. In addition, relevant education departments should formulate a scientific and perfect English teaching management standard system, and build a distinctive English teaching system, so as to realize the English learning management system from primary school to university. The students from learning English to college English learning content in primary school, the most suitable connection should not only cultivate the students"s ability of writing in English, but also cultivate students' English ability. Should the management mode of English education reform actively in China fundamentally major colleges and universities, the innovation of English teaching methods, each stage of scientific and reasonable teaching in the English learning content of systematic links, so as to each big university English language teaching to lay a firm foundation for the teaching.[8]

\section{Concluding remarks}

With the progress of the era, the College English teaching is to reform and improve constantly, the reform of English teaching, to a certain extent related to the future development of English education in china. Actively promote the reform of English teaching work, the school and the relevant teaching staff should actively innovate English teaching mode, set up the new concept of English teaching, establish the evaluation system of English test enough standard, implementation of quality education, English fundamentally so that is conducive to cultivate more excellent quality. Personnel from the fundamental.

\section{References:}

[1]Hardman P. Fear of Fever and the Limits of the Enlightenment: Selling Prison Reform in Late Eighteenth-Century Gloucestershire[J]. Cultural \& Social History, 2015, 10(4):511-531.

[2]Jia-He W. The Enlightenment of Ecology of Language on College English Teaching Reform[J]. Journal of Kaili University, 2008.

[3]Jiang S H. On the Enlightenment of the Traditional Theory Self-restraining in Privacy to the Reform of College English Teaching[J]. Journal of Heilongjiang College of Education, 2012.

[4]Li L. SCLT teaching model and its enlightenment on college English teaching reform[J]. Foreign Language World, 2002.

[5]Zhen Y I, Mei-Yu W U. Studies on Multiliteracies and Its Enlightenment to the College English

Teaching Reform in Our Country[J]. Journal of Chengdu Normal University, 2014.

[6]Wang R Y. The Enlightenment of Implicit Learning Theory to English Teaching of College

Campus Network[J]. Journal of Huaihua University, 2007. 
[7]Huang, LingYing. Teachers' understanding and implementation of a whole language approach to literacy in Taiwan : a study of early years' teachers' beliefs and practices[J]. Scandinavian Journal of Statistics, 2012, 39(4):681-694.

[8]Wear A. The Practice of Reform in Health, Medicine, and Science, 1500-2000 (review)[J]. Bulletin of the History of Medicine, 2008, 82(2):450-452. 